\title{
Green Building Materials Market-Growth, Trend and Opportunity: South Asian Perspective
}

\author{
Mridu Pavan Chakrabarty and Nitin Lekhwani
}

\begin{abstract}
Selection of building material is an important issue in building design and construction decision-making and environmental issues need to be incorporated into the evaluation process. Prices vary for different types of green building materials. South Asian Green Building material market has lots of challenges and opportunities ahead. The future prospects are bright, but the South Asian (particularly Indian) customers are yet to get through the Rubicon of opting for Green Building instead of conventional buildings. Greener building standards and the rising energy costs are the market's main propellants. Unfortunately, enforcement of energy standards is uneven and customers are highly price sensitive. There is tremendous potential for construction of Green Building in India. The main objective to concentrate in Green Building is that, green building has a potential to save $30 \%-40 \%$ energy with reduction of operating cost and enhance good health. Through this report, authors studied the Green Building material market in relation to embodied energy and $\mathrm{CO}_{2}$ emission from building material and analyzed the growth and trend of the materials in South Asian perspective over a period. For analysis authors have considered the city of Ahmedabad in India.
\end{abstract}

Index Terms - Cost analysis, $\mathrm{CO}_{2}$ emission, embodied Energy, energy efficient and green material.

\section{INTRODUCTION}

A green building is one which uses less water, optimizes energy efficiency, conserves natural resources, generates less waste and provides healthier spaces for occupants, as compared to a conventional building. Green building is the practice of creating structures and using processes that are environmentally responsible and resource-efficient throughout a building's life-cycle from sitting to design, construction, operation, maintenance, renovation and deconstruction. This practice expands and complements the classical building design concerns of economy, utility, durability, and comfort. Green building is also known as a sustainable or high performance building.

Materials such as cellulose, cotton, fiberglass and mineral wool are capturing the market for insulations due to their excellent properties. Development of green roofs with eco-friendly materials from various manufacturers has also driven the growth of the roofing application segment. Interior finishing materials including eco-friendly carpets, recycled tiles and VOC free glues \& paints are being consumed rapidly due to regulations regarding indoor environment quality and health hazards [1]. Wooden structures, steel with recycle

Manuscript received February 20, 2015; revised June 16, 2015.

The authors are with the Energy and Infrastructure, School of Petroleum Management, Pandit Deendayal Petroleum University, Gujarat, India (e-mail: mridu.cpgp14@spm.pdpu.ac.in, nitin.lpgp14@spm.pdpu.ac.in). content, autoclaved aerated concrete, engineered lumber and structural insulated panels for framing applications are expected to replace conventional materials. Hence, interior finishing and framing applications are expected to grow with healthy growth numbers over a period.

Building material selection is an important issue in building design and construction decision-making and environmental issues need to be incorporated into the evaluation process.

\section{LITERATURE REVIEW}

In building construction, the requirement of energy is large. It is in various forms. Materials which are required for construction, there manufacturing, transportation, actual use in construction and after construction, large amount of energy utilized. That form of energy is called as Embodied Energy. Secondly, there is good trend to use various green building materials in building construction. It will definitely helpful to make our building as Green Building. Production of Green material generally involves these types of material which are conventional, recyclable, waste products. Researchers are always trying to produce new building material, keeping various mix proportions, various conventional and non-conventional in gradients and taking all appropriate tests on them and conclude that this material is suitable for construction work. But no one tried to calculate their embodied energy along with all tests.

Buildings have a significant and continuous impact on the environment since they are responsible for a large portion of carbon emissions and also use considerable number of resources [2]. Buildings account for one-sixth of the world's fresh water withdrawals, one quarter of its wood harvest, and two-fifths of its material and energy flows [3]. The construction sector consumes considerable amount of energy from the production of basic building materials, its transportation and assembling called embodied energy. Energy conscious and eco-friendly development hold the key potential to significantly reduce thermal loads and electricity use in commercial buildings. Low embodied energy materials conserve energy and limit Green House Gases (GHG) emissions thus limiting the impact on the environment [4]. The energy in buildings may be looked from two different perspectives [5]. Firstly the energy that goes into the construction of the building using a variety of materials. Secondly the energy that is required to create a comfortable environment within the building during its lifetime. Embodied Energy is the sum of all the energy required to produce any goods or services, considered as if that energy was incorporated or 'embodied' in the product itself [5]. The 
concept can be useful in determining the effectiveness of energy-producing or energy-saving devices, or the "real" replacement cost of a building [6], and, because energy-inputs usually entail greenhouse gas emissions, in deciding whether a product contributes to or mitigates global warming. One fundamental purpose for measuring this quantity is to compare the amount of energy produced or saved by the product in question to the amount of energy consumed in producing it.

\section{GAP IDENTIFICATION}

So far going through various research papers in the Green Building sector, it is clear that Indian Green Building material market have lots of challenges and opportunities ahead. The future prospects are bright, but the Indian customers are yet to get through the Rubicon of opting for Green Building instead of conventional buildings. Also, the general awareness on Green Buildings in India is scare and scattered. The main objective and need to concentrate for Green Building is that, green Building has a potential to save $30 \%-40 \%$ energy with reduction of operating cost and enhance good health. Moreover, the embodied energy of building materials and the $\mathrm{CO}_{2}$ emission by them is of importance during the research [7]-[10].

Authors have analyzed the Indian market/industry on the basis of normal cement produced and consumed for construction in the last ten years and how much energy and $\mathrm{CO}_{2}$ emission could have been saved and reduced by using Fly Ash, which is a post-consumer waste and Sandfree cement (Green material) instead of conventional cement. Energy saved can be directly related to monetary benefits [11]-[14].

\section{RESEARCH METHODOLOGY}

This is a descriptive research undertaken, pertaining to factors taken into account during analysing green building materials market. The data used in this project are the production and consumption figures of cement which is in million tonnes and related embodied energy and $\mathrm{CO}_{2}$ emission which are in $\mathrm{MJ} / \mathrm{Kg}$ and $\mathrm{Kg} / \mathrm{Kg}$ respectively.

The research is an applied research as it uses the research theories and methods for a commercially driven purpose of getting to know the green building material overall demand and supply. The research type is descriptive because the data description is factual, accurate and systematic, but it cannot describe what caused a situation. Variation in the embodied energy (MJ) and $\mathrm{CO}_{2}$ emission are checked for normal cement mortar and cement mortar with $20 \%, 35 \%$ and $55 \%$ fly ash.

\section{A. Data Collection}

Both Primary and secondary data are collected from various sources as a basic instrument or tool for the purpose of this research.

\section{B. Data Source}

Various data sources for the research are as follows: Green Building construction companies, Green Building materials supplier, research works on Green building, etc.

\section{DATA ANALYSIS}

\section{A. Methodology}

A quantitative analysis of the data collected has been done using inferential statistics. Authors have done the linear regression. Scenario writing has been done which consists of developing a conceptual scenario of the future based on a well-defined set of assumptions. Different set of assumptions lead to different scenarios. Data analysis has been divided into four segments:

1) Linear regression is used to analyse the month wise production and consumption data of Cement in India from 2005 to 2014. Same analysis is carried out for cement concrete, cement concrete with $80 \%$ cement $+20 \%$ Flyash, $65 \%$ cement $+35 \%$ Flyash and $45 \%$ cement $+55 \%$ Flyash. Consumption of cement is replaced by $10 \%, 20 \%$ and $30 \%$ of Sandfree cement which is a green building material and data is analysed using linear regression over a period of ten years from 2005 to 2015.

2) Embodied energy and $\mathrm{CO}_{2}$ emission by cement concrete is checked and compared with that of cement concrete with $80 \%$ cement $+20 \%$ Flyash, $65 \%$ cement $+35 \%$ Flyash and $45 \%$ cement $+55 \%$ Flyash.

3) Similarly, scenario analysis has been done by replacing the consumption of cement with Green building material, i.e., Sandfree cement. $10 \%, 20 \%$ and $30 \%$ replacement are done and the embodied energy and $\mathrm{CO}_{2}$ emission are compared for the given situations.

4) Financial analysis is done by calculating the cost incurred in using normal cement for construction instead of green cement (Sandfree cement). Comparison done by finding the amount saved in the process over a span of five years.

\section{B. Data Used}

Embodied energy and $\mathrm{CO}_{2}$ emission mentioned in Table I, are the amount released during the production of the particular material. Moreover, prices of normal cement and sandfree cement (which is greener than normal cement) are given in Table II. The prices taken are for the city of Ahmedabad in India over a period of ten years (2005-2014). The data from Table I and Table II are used for carrying out the analysis.

\section{Analysis I: Correlation, Variability and Significance Check of Cement Production and Consumption with Time (Month)}

The data shows the mean, correlation, adjusted $\mathrm{R}$ square and significance of all the items mentioned in Table III, month wise. It shows the fluctuation in demand and supply of cement industry in India. We took the data of 10 years or 120 months

Correlation column shows the Pearson correlation coefficient which shows the correlation between the items mentioned in Table III and the number of months or time. A very strong positive correlation is seen here for every case as the value is well above 0.95 . It means the items in reference will grow with the time or months.

Adjusted R Square shows percentage of variability. It basically talks about the perfect positive correlation or perfect negative correlation. It shows all items depicts $95 \%$ and above of variability and showing the strong positive correlation between the items in reference and months. 
TABLE I: EMBODIED ENERGY AND CO ${ }_{2}$ EMISSION OF SOME MATERIALS (SOURCE: CANNON DESIGN, 2013)

\begin{tabular}{|l|c|c|}
\hline Items & Embodied Energy (MJ/Kg) & $\mathbf{C O}_{\mathbf{2}}$ emission $\left.\mathbf{( K g} / \mathbf{K g}\right)$ \\
\hline Cement & 5.8 & 0.9368 \\
\hline Cement Mortar (1:3) & 1.33 & 0.1311 \\
\hline $\mathbf{8 0 \% ~ C e m e n t ~ + ~ 2 0 \% ~ F l y ~ A s h ~}$ & 0.509 & 0.107 \\
\hline $\mathbf{6 5 \%}$ Cement + 35\% Fly Ash & 0.367 & 0.0755 \\
\hline $\mathbf{4 5 \% ~ C e m e n t ~ + ~ 5 5 \% ~ F l y ~ A s h ~}$ & 0.34 & 0.0693 \\
\hline Sandfree Cement & 5.2 & 0.843 \\
\hline
\end{tabular}

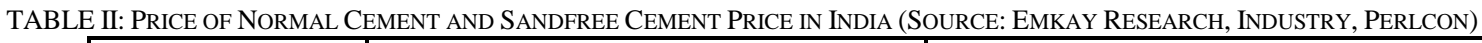

\begin{tabular}{|c|c|c|}
\hline Year & Cement $(\mathbf{R s}) / \mathbf{5 0}$ Kg bag & Sandfree Cement (Green building material) (Rs)/40 Kg bag \\
\hline 2005 & Rs. 203.00 & NA \\
\hline 2006 & Rs. 212.50 & NA \\
\hline 2007 & Rs. 222.50 & NA \\
\hline 2008 & Rs. 233.00 & NA \\
\hline 2009 & Rs. 244.00 & NA \\
\hline 2010 & Rs. 255.50 & NA \\
\hline 2011 & Rs. 267.50 & NA \\
\hline 2012 & Rs. 280.00 & NA \\
\hline 2013 & Rs. 293.00 & NA \\
\hline 2014 & Rs. 308.00 & Rs. 500.00 \\
\hline 2015 & Rs. 320.00 & Rs. 500.00 \\
\hline
\end{tabular}

TABLE III: VALUES OBTAINED FROM LINEAR REGRESSION ON VARIOUS PARAMETERS (2005-2014)

\begin{tabular}{|c|c|c|c|c|c|}
\hline Sr No. & Parameter & Mean & Correlation & Adjusted R Square & Significance (Anova) \\
\hline 1 & Production of cement & 16.7709 million tonnes & .978 & .957 & 0.000 \\
\hline 2 & Consumption of cement & 16.5420 million tonnes & .989 & .978 & 0.000 \\
\hline 3 & Embodied energy of cement & $97271316666.6 \mathrm{MJ} / \mathrm{Kg}$ & .978 & .957 & 0.000 \\
\hline 4 & $\mathrm{CO}_{2}$ emission of cement & $15710994.73 \mathrm{Kg} / \mathrm{Kg}$ & .978 & .957 & 0.000 \\
\hline 5 & Embodied energy of cement mortar & $72043440000 \mathrm{MJ} / \mathrm{Kg}$ & .989 & .978 & 0.000 \\
\hline 6 & $\mathrm{CO}_{2}$ emission of cement mortar & $7101424800 \mathrm{Kg} / \mathrm{Kg}$ & .989 & .978 & 0.000 \\
\hline 7 & Embodied energy of $80 \%$ cement $+20 \%$ fly ash & $27571512000 \mathrm{MJ} / \mathrm{Kg}$ & .989 & .978 & 0.000 \\
\hline 8 & $\mathrm{CO}_{2}$ emission of $80 \%$ cement $+20 \%$ fly ash & $5795976000 \mathrm{Kg} / \mathrm{Kg}$ & .989 & .978 & 0.000 \\
\hline 9 & Embodied energy of $65 \%$ cement $+35 \%$ fly ash & $19879656000 \mathrm{MJ} / \mathrm{Kg}$ & .989 & .978 & 0.000 \\
\hline 10 & $\mathrm{CO}_{2}$ emission of $65 \%$ cement $+35 \%$ fly ash & $4089684000 \mathrm{Kg} / \mathrm{Kg}$ & .989 & .978 & 0.000 \\
\hline 11 & Embodied energy of $45 \%$ cement $+55 \%$ fly ash & $18417120000 \mathrm{MJ} / \mathrm{Kg}$ & .989 & .978 & 0.000 \\
\hline 12 & $\mathrm{CO}_{2}$ emission of $45 \%$ cement $+55 \%$ fly ash & $3753842400 \mathrm{Kg} / \mathrm{Kg}$ & .989 & .978 & 0.000 \\
\hline 13 & $10 \%$ check embodied energy & $94951080000 \mathrm{MJ} / \mathrm{Kg}$ & .989 & .978 & 0.000 \\
\hline 14 & $10 \%$ check $\mathrm{CO}_{2}$ emission & $15341381640 \mathrm{Kg} / \mathrm{Kg}$ & .989 & .978 & 0.000 \\
\hline 15 & $20 \%$ check embodied energy & $93958560000 \mathrm{MJ} / \mathrm{Kg}$ & .989 & .978 & 0.000 \\
\hline 16 & $20 \%$ check $\mathrm{CO}_{2}$ emission & $15186217680 \mathrm{Kg} / \mathrm{Kg}$ & .989 & .978 & 0.000 \\
\hline 17 & $30 \%$ check embodied energy & $92966040000 \mathrm{MJ} / \mathrm{Kg}$ & .989 & .978 & 0.000 \\
\hline 18 & $30 \%$ check $\mathrm{CO}_{2}$ emission & $15031053720 \mathrm{Kg} / \mathrm{Kg}$ & .989 & .978 & 0.000 \\
\hline
\end{tabular}

Significance (Anova) column explains that the correlation we got in previous column is statistically significant or not. Here, 0.000 value explains that the correlation between the items in reference in Table III and monthly are strongly significant.

Term 'Unstandardized Coefficients' in Table IV explains what will be the consumption of cement if we increase the number of months by 1 . For example: the value of months is .124 means if we increase the number of month by 1 than the production of cement will increase by .124 million tone. Which depict the increased production of cement is possible in India as we move forward with time. The term 'Constant' means intercept here. It means the value of production will be 9.278 if the number of month is 0 , which don't make any sense in this context. Same can be inferred for other items in Table IV.

For example: If we take the case of production of cement in Table IV with $95 \%$ confidence interval for correlation. The confidence interval for intercept is in the range of 8.94 to 9.61 .
It means that at month 0 , the production of cement will be in the range of 8.94 to 9.61 million tonne. For the months, the range is .119 to .129 , it means by the increment of 1 month the production of cement will increase in the range of .119 to .129 . The same follows for all the items in Table IV.

D. Analysis II: Embodied Energy and $\mathrm{CO}_{2}$ Emission by Mixture of Different Proportion of Cement and

Post-consumer Waste (Flyash)

In this analysis, Embodied energy and $\mathrm{CO}_{2}$ emission by cement concrete is checked and compared with that of cement concrete with $80 \%$ cement $+20 \%$ Flyash, $65 \%$ cement $+35 \%$ Flyash and $45 \%$ cement $+55 \%$ Flyash. The following results are obtained:

The embodied energy of three different mixtures of cement and fly ash has been calculated from 2005 to 2014 . The three mixtures have specific ratio between cement and fly ash which are as follows such as mixture 1 (8:2), mixture 2 (6.5:3.5) and mixture 3 (4.5:5.5) respectively. The slope of mixture 1, mixture 2 and mixture 3 are 259779403.6, 
187306564.1 and 173526517.1 respectively as shown in Fig. 1. This clearly signifies that the rate at which embodied energy is increasing with time is maximum and minimum for mixture 1 and mixture 3 respectively. This is due to disparity in embodied energy of cement and fly ash (less embodied energy per kilogram as compared to cement).

TABLE IV: VALUES OBTAINED FROM LINEAR REGRESSION ON VARIOUS PARAMETERS (2005-2014)

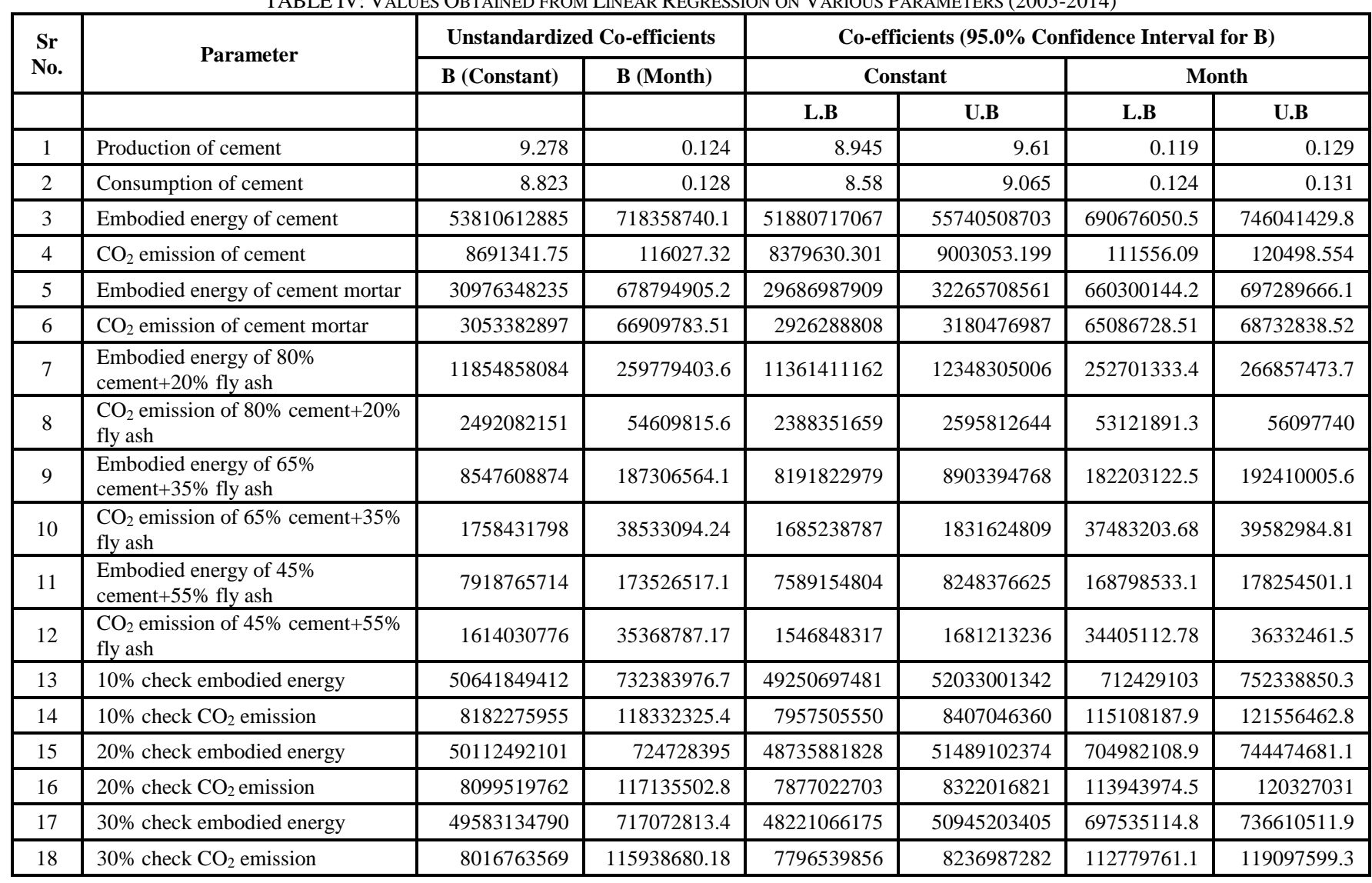

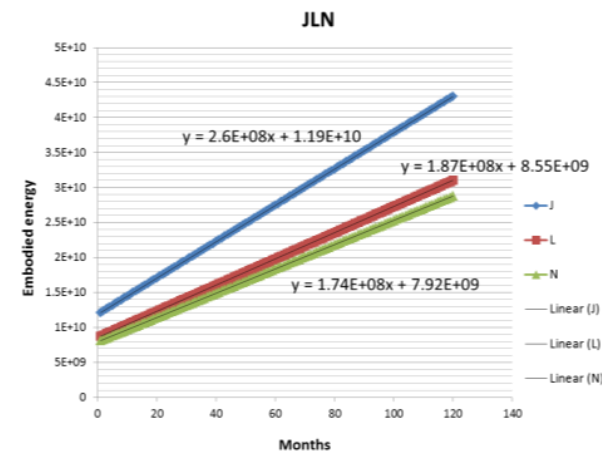

Fig. 1. Embodied energy from 2005 to 2014, J: Embodied energy of $80 \%$ Cement $+20 \%$ Fly Ash (MJ); L: Embodied energy of $65 \%$ Cement $+35 \%$ Fly Ash (MJ); N: Embodied energy of 45\% Cement $+55 \%$ Fly Ash (MJ).

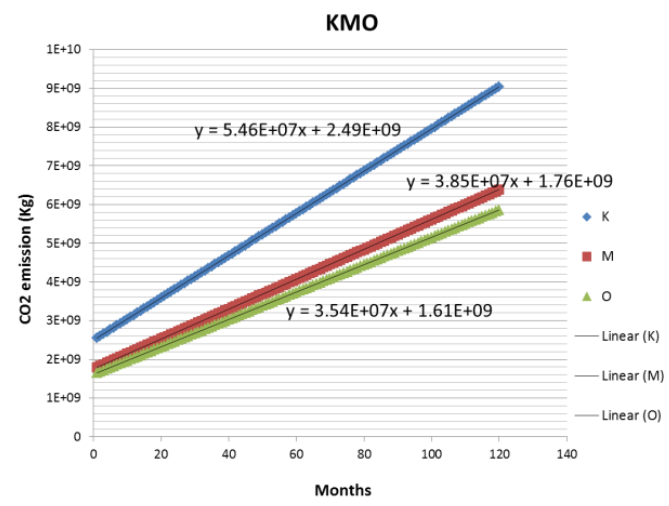

Fig. 2. $\mathrm{CO}_{2}$ emission from 2005 to 2014, K: $80 \%$ Cement $+20 \%$ Fly Ash $\mathrm{CO} 2$ emission (Kg); $\mathrm{M}: 65 \%$ Cement $+35 \%$ Fly Ash $\mathrm{CO}_{2}$ emission $(\mathrm{Kg})$; O: $45 \%$ Cement $+55 \%$ Fly Ash $\mathrm{CO}_{2}$ emission $(\mathrm{Kg})$.
The $\mathrm{CO}_{2}$ emission of three different mixtures of cement and fly ash has been calculated from 2005 to 2014. The three mixtures have specific ratio between cement and fly ash which are as follows such as mixture $1(8: 2)$, mixture 2 (6.5:3.5) and mixture 3 (4.5:5.5) respectively. The slope of mixture 1, mixture 2 and mixture 3 are 54609815.6, 38533094.24 and 35368787.17 respectively as shown in Fig. 2. This clearly signifies that the rate at which $\mathrm{CO}_{2}$ emission is increasing with time and is maximum and minimum for mixture 1 and mixture 3 respectively. This is due to disparity in $\mathrm{CO}_{2}$ emission of cement and fly ash (less $\mathrm{CO}_{2}$ emission per kilogram as compared to cement).

\section{E. Analysis III: Embodied Energy and $\mathrm{CO}_{2}$ Emission When Cement Consumption in Replaced by Sandfree Cement in Different Proportion}

In this analysis, scenario check has been done by replacing the consumption of cement with Green building material, i.e., Sandfree cement. 10\%, 20\% and 30\% replacement are done and the embodied energy and $\mathrm{CO}_{2}$ emission are compared for the given situations. The embodied energy of three combinations of cement and green building material replacement of cement in India has been calculated from 2005 to 2014. The three mixtures having specific ratio of cement and green building replacement are as follows: Combination 1 (9:1), Combination 2 (8:2) and Combination 3 (7:3) respectively. The slope of mixture 1 , mixture 2 and mixture 3 are $732383976.7,724728395$ and 717072813.4 respectively as shown in Fig. 3. This clearly signifies that the rate at which 
embodied energy is increasing with time is maximum and minimum for mixture 1 and mixture 3 respectively. The minimum rate at which embodied energy is increasing with time is almost similar for combinations 2 and 3. But in the longer run, the differences between them can be clearly identified. This is due to disparity in embodied energy of cement and its green building replacement (less embodied energy per kilogram as compared to cement).

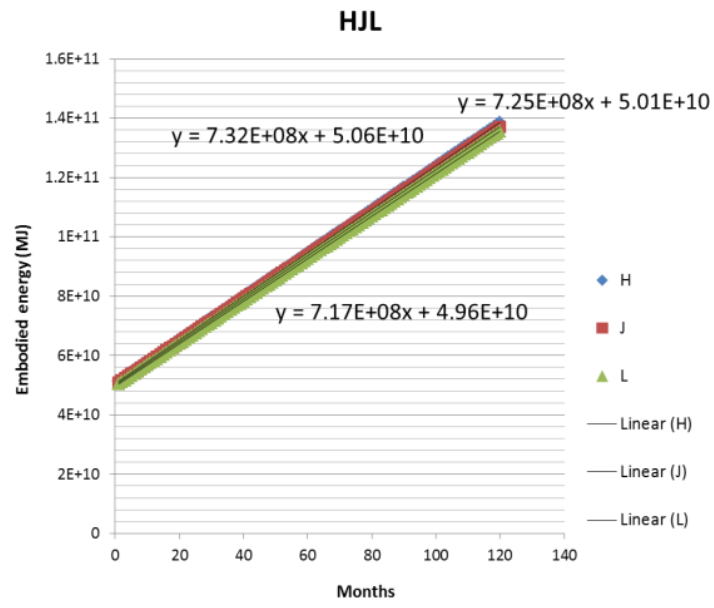

Fig. 3. Embodied energy from 2005 to 2014, H: $10 \%$ of cement consumption replaced by Green cement; J: $20 \%$ of cement consumption replaced by Green cement; L: $30 \%$ of cement consumption replaced by Green cement.

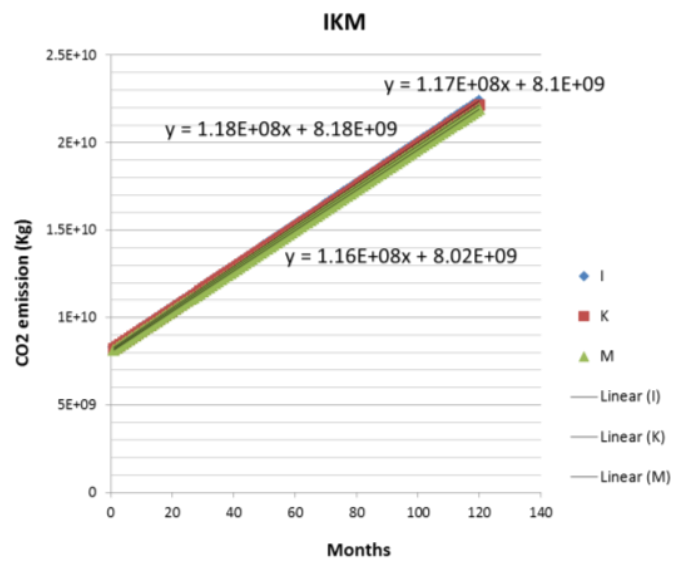

Fig. 4. $\mathrm{CO}_{2}$ emission from 2005 to 2014 , I: $10 \%$ of cement consumption replaced by Green cement; K: $20 \%$ of cement consumption replaced by Green cement; M: $30 \%$ of cement consumption replaced by Green cement.

The $\mathrm{CO}_{2}$ emission of three combinations of cement and green building material replacement of cement in India has been calculated from 2005 to 2014 . The three mixtures having specific ratio of cement and green building replacement are as follows: Combination 1 (9:1), Combination 2 (8:2) and Combination 3 (7:3) respectively. The slope of mixture 1 , mixture 2 and mixture 3 are $118332325.4,117135502.8$ and 115938680.18 respectively as shown in Fig. 4. This clearly signifies that the rate at which $\mathrm{CO}_{2}$ emission is increasing with time is maximum and minimum for mixture 1 and mixture 3 respectively. This is due to disparity in $\mathrm{CO}_{2}$ emission of cement and its green building replacement (less $\mathrm{CO}_{2}$ emission per kilogram as compared to cement).

\section{F. Analysis IV: Financial Analysis}

Here, financial analysis is done by calculating the cost incurred in using normal cement for construction instead of green cement (Sandfree cement). Comparison is done by finding the amount saved in the process over a span of five years.

\section{1) Data used}

TABLE V: Citywise TONNAGE CALCUlator (SOURCE: BiJliBachaO)

\begin{tabular}{|c|c|c|c|c|c|}
\hline \multicolumn{6}{|c|}{ Citywise Tonnage Calculator (Inverter AC) } \\
\hline & & \multicolumn{2}{|c|}{$\begin{array}{c}\text { Daytime Summer } \\
\text { Temp }\end{array}$} & \multicolumn{2}{c|}{ Multiplier } \\
\hline Sr No. & CITY & $\begin{array}{c}\text { Avg } \\
\text { Temp } \\
\left({ }^{\circ} \text { C) }\right.\end{array}$ & $\begin{array}{c}\text { Max } \\
\text { Temp }\left({ }^{\circ} \text { C) }\right.\end{array}$ & $\begin{array}{c}\text { Non } \\
\text { Sunny } \\
\text { Room, } \\
\text { Ground } \\
\text { Floor }\end{array}$ & $\begin{array}{c}\text { Sunny } \\
\text { Room } \\
\text { Top } \\
\text { Floor }\end{array}$ \\
\hline 1 & Panaji & 34 & 37 & 750 & 950 \\
\hline 2 & Ahmedabad & 42 & 46 & 950 & 1250 \\
\hline 3 & Mumbai & 33 & 37 & 650 & 850 \\
\hline 4 & Nagpur & 39 & 43 & 850 & 1150 \\
\hline 5 & Pune & 36 & 40 & 750 & 950 \\
\hline 6 & Baroda & 39 & 43 & 850 & 1150 \\
\hline 7 & Surat & 41 & 45 & 950 & 1250 \\
\hline
\end{tabular}

\section{2) Assumptions}

- Room Height Max 10Ft

- Room considered is 100 sq. ft.

- 2-4 persons

- 01 TV in room

- Curtains on Glass windows

- Coverage area of both normal cement and Sandfree cement is same.

- Using Split Air Conditioner.

- AC consumption for the whole year.

- Electricity consumption will not reduce in 70:30 ratio. We have assumed the reduction in 50:50 ratio because the use of cement will be uniform on the walls.

- The power input for AC is 1350 Watt-hour.

- Reduction in consumption of electricity will be $25-30$ percent by using Sandfree cement which is greener than normal cement.

TABLE VI: TONNAGE REQUiRED In AHMEDABAD (SOURCE: BIJLIBACHAO)

\begin{tabular}{|c|c|c|c|c|}
\hline \multicolumn{2}{|c|}{ Room Size } & \multicolumn{2}{c|}{ Tonnage Reqd } \\
\hline (mt) & $\begin{array}{c}\text { Breadth } \\
\text { (Mt) }\end{array}$ & $\begin{array}{c}\text { Area } \\
\text { (Sq } \\
\text { Feet) }\end{array}$ & $\begin{array}{c}\text { (2-4 people) } \\
\text { Non-sunny } \\
\text { room, } \\
\text { Ground } \\
\text { Floor }\end{array}$ & $\begin{array}{c}\text { (2-4 } \\
\text { people) } \\
\text { Sunny } \\
\text { room, Top } \\
\text { Floor }\end{array}$ \\
\hline 2 & 2 & 43 & 0.32 & 0.42 \\
\hline 2 & 2.5 & 54 & 0.4 & 0.52 \\
\hline 2.5 & 2.5 & 67 & 0.49 & 0.65 \\
\hline 2.5 & 3 & 81 & 0.59 & 0.78 \\
\hline 3 & 3 & 97 & 0.71 & 0.94 \\
\hline 3 & 3.5 & 113 & 0.83 & 1.09 \\
\hline 3.5 & 3.5 & 132 & 0.97 & 1.28 \\
\hline 3.5 & 4 & 151 & 1.11 & 1.46 \\
\hline 4 & 4 & 172 & 1.27 & 1.67 \\
\hline 4 & 4.5 & 194 & 1.43 & 1.88 \\
\hline
\end{tabular}

Considering $1000 \mathrm{sq} \mathrm{ft}$ home and the calculations in Table VII and Table VIII are carried out using data from Table V and Table VI. Table $\mathrm{V}$ provides the multiplier value required 
for calculation of tonnage of air conditioner for a particular city. Table VI gives the tonnage in the city of Ahmedabad for different room sizes. Cost incurred by using normal cement, sandfree cement and mix proportion of both for construction over a period of five years is calculated as shown in Table VII and in Table VIII, cost comparison is done under three different conditions: 1) Replacing the use of normal cement by sandfree cement, 2) Replacing normal cement by (70\% cement $+30 \%$ sandfree) and, 3) Replacing Sandfree cement by ( $70 \%$ cement $+30 \%$ sandfree) .

\begin{tabular}{|c|c|c|c|c|c|}
\hline Items & Normal Cement & Sandfree cement & \multicolumn{3}{|c|}{$70 \%$ Cement $+30 \%$ Sandfree } \\
\hline \multirow[b]{2}{*}{ Requirement of cement } & $20 \mathrm{~kg} / \mathrm{sq} . \mathrm{ft}$ & $20 \mathrm{~kg} / \mathrm{sq} . \mathrm{ft}$ & 0.7 & 0.3 & Total \\
\hline & $20 * 100=2000 \mathrm{~kg}$ & $20 * 100=2000 \mathrm{~kg}$ & $2000 * 0.7=1400 \mathrm{~kg}$ & $\begin{array}{l}2000 * 0.3= \\
600 \mathrm{~kg}\end{array}$ & $2000 \mathrm{~kg}$ \\
\hline No. of bags $(1 \mathrm{bag}=50 \mathrm{~kg})$ & $2000 / 50=40$ bags & $2000 / 50=40 \mathrm{bags}$ & $1400 / 50=28$ & $600 / 50=12$ & 40 bags \\
\hline $\begin{array}{c}\text { Total cost of cement and sandfree } \\
\text { cement }\end{array}$ & $40 * 320=$ Rs. 12800 & $40 * 500=$ Rs. 20000 & $28 * 320=$ Rs. 8960 & $\begin{array}{c}12 * 500=\mathrm{Rs} \\
6000\end{array}$ & Rs 14960 \\
\hline Calculated AC tonnage & 0.83 (we are taking it 1 ) & $\begin{array}{l}0.83 \text { (we are taking it } \\
1 \text { ) }\end{array}$ & 0.83 & 0.83 & 0.83 \\
\hline $\begin{array}{l}\text { Consumption electricity unit by } \\
\text { AC per hour }\end{array}$ & 1.35 units/hour & 1 unit/hour & $1.35 * 0.5=0.675$ & $1 * .5=0.50$ & 1.175 units/hour \\
\hline Daily usage (10 hour) & $1.35^{*} 10=13.5$ units & $1 * 10=10$ units & $.675 * 10=6.75$ units & $.50 * 10=5$ units & 11.75units \\
\hline cost of 1 unit=Rs 5/unit & $13.5 * 5=$ Rs. $67.5 /$ day & $10^{*} 5=$ Rs $50 /$ day & $6.75 * 5=$ Rs. $33.75 /$ day & $5 * 5=$ Rs. $25 /$ day & Rs.58.75/day \\
\hline Yearly cost of AC & $\begin{array}{c}67.5 * 30 * 12= \\
\text { Rs. } 24300\end{array}$ & $50 * 30 * 12=$ Rs. 18000 & $\begin{array}{c}33.75 * 30 * 12=\text { Rs. } 1215 \\
0\end{array}$ & $\begin{array}{c}25 * 30 * 12= \\
\text { Rs. } 9000\end{array}$ & Rs. 21150 \\
\hline Cost for 5 years & $24300 * 5=$ Rs. 121500 & $18000 * 5=$ Rs. 90000 & $12150 * 5=$ Rs. 60750 & $\begin{array}{l}9000 * 5= \\
\text { Rs. } 45000\end{array}$ & Rs. 105750 \\
\hline
\end{tabular}

Note: Rs = Indian Rupees, Rs $1=0.0138$ Euro as of 17th May, 2015

TABLE VIII: COST COMPARISON UNDER THREE DIFFERENT CONDITIONS

\begin{tabular}{|c|c|c|c|}
\hline & $\begin{array}{c}\text { I. Replacing Cement by } \\
\text { Sandfree }\end{array}$ & $\begin{array}{c}\text { II. Replace normal cement by (70\% } \\
\text { cement+30\% sandfree) }\end{array}$ & $\begin{array}{c}\text { III. Replace Sandfree cement by } \\
\text { (70\% cement+30\% sandfree) }\end{array}$ \\
\hline $\begin{array}{c}\text { Total cost savings in electricity } \\
\text { after 1 year }\end{array}$ & $24300-18000=$ Rs 6300 & $24300-21150=$ Rs 3150 \\
\hline $\begin{array}{c}\text { Extra cost paid for } \\
\text { construction }\end{array}$ & $20000-12800=$ Rs 7200 & $14960-12800=$ Rs 2160 & $18000-21150=$ Rs $(3150)$ \\
\hline Net loss or profit & $6300-7200=$ Rs $(900)$ & $3150-2160=$ Rs 990 & $14960-20000=$ Rs $(5040)$ \\
\hline Remarks & NA & $\begin{array}{c}\text { Future value of } 990 \text { at } 10 \% \text { rate and for } 5 \text { years } \\
\text { is } 1595\end{array}$ & $\begin{array}{c}\text { Future value of } 1890 \text { at } 10 \% \text { rate of } \\
\text { interest and 5 years is 3045 }\end{array}$ \\
\hline
\end{tabular}

It is seen that complete replacement of normal cement by Sandfree cement is not feasible under our assumed conditions in terms of monetary benefit. But, by replacing normal cement and Sandfree Cement with $(70 \%$ Cement $+30 \%$ Sandfree cement), monetary benefit can be achieved as derived from the calculations.

\section{CONCLUSION}

Generally, researchers are always trying to find out new building material which relates with recycle of material, use of waste material as in-gradients etc. This study helps to determine the embodied energy and $\mathrm{CO}_{2}$ emission for construction material such as cement. Post-consumer wastes like glasses, plastics, tyres, fly ash, etc., can be used with cement concrete to make the building material greener. After analysis, it is seen that increasing the quantity of cement in concrete automatically increase the Embodied energy value. Same is the case with $\mathrm{CO}_{2}$ emission.

Financial benefits as per the study very well depict the need of using Green Building material in construction sector.

\section{ACKNOWLEDGMENT}

Authors expresses their warm thanks to Prof. Dr. Akash
Patel and Prof. Dr. Pramod Paliwal, School of Petroleum Management; Prof. Dr. Ravi Gor, Director - Dr. Babasaheb Ambedkar Open University, for their valuable support and guidance.

Also special thanks to Perlcon Premix Pvt. Ltd., Ahmedabad, India, which deals in Green Building materials supply for providing the required data during the study.

\section{REFERENCES}

[1] Transparency Market Research, "Green building materials market Global industry analysis, size, share, growth, trends and forecast, 2013 - 2019," Jan.2014, pp. 1-63.

[2] M. Montoya, Green Building Fundamentals: A Practical Guide to Understanding and Applying Fundamental Sustainable Construction Practices and LEED Green Building Rating System, Pearson Education Publisher Edition, 2009, p. 3.

[3] D. M. Roodman and N. Lenssen, "A building revolution: How ecology \& health concerns are transforming construction," World Watch Institute, Washington DC, 1995, p. 5.

[4] A. Kumar, D. Buddhi, and D. S. Chauhan, "Indexing of building materials with embodied operational energy and environmental sustainability with reference to green building," Journal of Pure and Applied Science and Technology, vol. 2, no. 1, pp.11-22, 2012.

[5] R. Deshmukh and A. More, "Low energy green materials by embodied energy analysis," International Journal of Civil and Structural Engineering Research, vol. 2, issue 1, pp. 58-65, April 2014.

[6] G. H. Kats, Green Building Cost and Financial Benefits, Massachusetts Technology Collaborative, USA, 2003, pp. 1-10. 
[7] A. M. Omer, "Energy, environment and sustainable development," Renewable and Sustainable Energy Reviews, pp. 2265-2268, May 2007.

[8] O. P. Akadiri, "Development of a multi-criteria approach for the selection of sustainable materials for Building projects," Thesis, University of Wolverhampton, pp. 2-6, 2011.

[9] S. Shams, K. Mahmud, and M. Al-Amin, "A comparative analysis of building materials for sustainable construction with emphasis on $\mathrm{CO}_{2}$ reduction," Int. J. Environment and Sustainable Development, vol. 10 no. 4, pp. 364-368, 2011

[10] H. T. Tatale and S. S. Kulkarni, "Dry mix mortar and its market potential in maharashtra (India) - An advance technology based material," International Journal of Engineering Research \& Technology (IJERT), vol. 2, issue 8, pp. 616-617, 2013.

[11] A. H. Makwana and Jayeshkumar Pitroda, "A study on region wise price variation of construction raw materials using frequency analysis through SPSS software," International Journal of Engineering Trends and Technology (IJETT), vol. 4, issue 7, pp. 3233-3241, July 2013.

[12] India Brand Equity Foundation, "Cement: August 2014 report for India," pp. 7-13, 2014.

[13] B. Lee, M. Trcka, and J. Hensen, "Embodied energy of building materials and green building rating systems - A case study for industrial halls," Materials Innovation Institute (M2i), Delft, The Netherlands, Sustainable cities and societies, vol. 1, no. 2, pp. 67-71.

[14] R. Jones, M. McCarthy, and M. Newlands, "Fly ash route to low embodied CO2 and implications for concrete construction," presented at World of Coal Ash Conference, Denver, USA, May 2011.

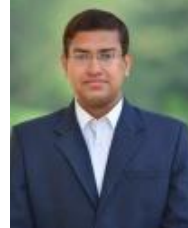

Mridu Pavan Chakrabarty was born on July 1, 1987 in Guwahati, Assam, India. He has done his bachelor's degree in mechanical engineering in 2010 from Assam Engineering College, Assam, India.

Right now he is pursuing his master degree in business administration in energy \& infrastructure from School of Petroleum Management, Pandit Deendayal Petroleum University, Gujarat, India.

He has three years of work experience in machine designing dealing mainly with pneumatic and hydraulic machines, during his tenure in DENSO, India.

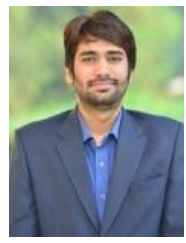

Nitin Lekhawani was born on September 15, 1991 in Jodhpur, Rajasthan, India. He has done his bachelor's degree in mechanical engineering from Jodhpur Institute of Engineering \& Technology, Jodhpur. He has completed his engineering in 2013 with honors. Now he is pursuing his master degree in business administration in energy and infrastructure sector, from School of Petroleum Management, Pandit Deendayal Petroleum University, Gandhinagar, Gujarat, India. He has done a research project on "Fabricating a set up for aluminum foam". 